\title{
Low Total Lymphocyte Count as the Risk of Hospital Acquired Malnutrition in Children
}

\author{
Dian Sulistya Ekaputri, I Gusti Lanang Sidiartha, I Gusti Ayu Putu Eka Pratiwi \\ Department of Child Health, Faculty of Medicine, Universitas Udayana/Sanglah General Hospital, Denpasar, Indonesia
}

Background: Hospital Acquired Malnutrition (HAM) is characterized by inadequate nutritional therapy and the risk of developing malnutrition during the hospital stay. In clinical practice, there are many measurements to determine nutritional status. Total lymphocyte count (TLC) is associated with impaired function of immune system in malnutrition. The purpose of this study was to evaluate the prognostic value of TLC to the occurrence of HAM in pediatric patients.

Materials and Methods: This an observational study with a prospective cohort design. Subjects were assessed for weight at the first day of hospitalization, then the subjects were followed until they were discharged. Body weight was re-measured on discharge to determine the presence or absence of HAM. This research was conducted at Sanglah Hospital from MayDecember 2019. Subjects who met the inclusion and exclusion criteria were enrolled in the study.

Results: Among 120 subjects, 55 subjects or $45.8 \%$ were malnourished on admission. Subjects with a low TLC compared to a normal TLC had a 3.9-fold risk of experiencing hospital acquired malnutrition (95\% Confidence Interval: 1.59 to 7.19 , $p=0.001$ ). Subjects who had a low TLC had HAM of $61.8 \%$, while subjects who had a normal TLC had HAM of $32.3 \%$. In multivariate analysis, low TLC was the only risk factor for HAM in this research.

Conclusion: This study proved that low TLC is the risk of HAM. Total lymphocyte count could be used as predictor of the risk of HAM in hospitalization children.

Keywords: hospital malnutrition, total lymphocyte, children

\section{Introduction}

Hospital Acquired Malnutrition (HAM) is characterized by inadequate nutritional therapy and the risk of developing malnutrition during the hospital stay. Hospital malnutrition is a condition resulting from suboptimal attention to children's nutritional status.
The data show that malnutrition in children is still common in both developed and developing countries. ${ }^{1}$ Malnutrition in children is still a problem in the health sector. The prevalence varies from $6.1 \%$ to $53 \% .^{2}$ The prevalence of malnutrition in Sanglah General Hospital is $30 \% .^{3}$ Research at Cipto Mangunkusumo General Hospital found that the number of children who experience

Date of submission: September 15, 2020

Last Revised: November 4, 2020

Accepted for publication: November 5, 2020

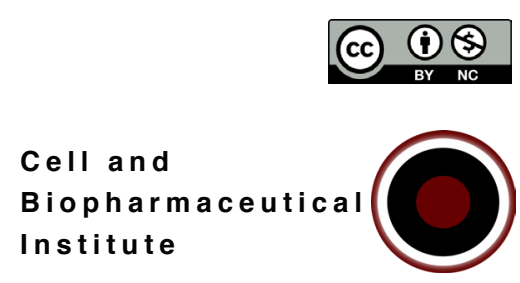

Corresponding Author:

Dian Sulistya Ekaputri

Department of Child Health, Faculty of Medicine

Universitas Udayana/Sanglah General Hospital

J. P.B. Sudirman, Denpasar, Bali 80232, Indonesia

e-mail: diansulistyaekaputri@gmail.com

Cell and
Biopharmaceutica
Institute 
malnutrition, after 14 days of treatment. ${ }^{4}$ A reduction in body weight was reported in $9.17 \%$ of patients with normal nutritional status on discharge from the hospital. ${ }^{5}$ Hospital malnutrition will affect many things, namely increased length of stay, increased mortality, delayed recovery, and increased treatment costs. Malnutrition is closely related to infection, so preventing HAM or detecting the presence of HAM early and treating it immediately is a beneficial action for both patients and hospital administrators. ${ }^{3}$ Patients experience HAM according to Walker and Hendricks if there is a weight loss of more than 2 percent in weight loss. A week or more than 5 percent in a month or more than 7.5 percent in 3 months or more than 10 percent in 6 months. ${ }^{6}$

Malnutrition has been shown to adversely affect the clinical outcome of patients. Depletion of body cells is caused by decreased intake or assimilation of energy and protein. Inflammation is related to the mechanisms of disease that cause anorexia and changes in body composition and the presence of metabolic stress. ${ }^{2}$ In clinical practice, there are many measurements to determine nutritional status. Parameters such as albumin levels, inflammatory markers such as C-reactive protein (CRP), or total lymphocyte count (TLC) can be associated with the risk of malnutrition. ${ }^{2}$

There was a correlation between TLC $<1200$ cells/ $\mathrm{mm}^{3}$ and nutritional status in adults. ${ }^{7}$ The low TLC as a component of routine complete blood counts is related to malnutrition so that the number of lymphocytes can be used as a parameter of nutritional status and to predict prognosis. $^{7}$

There have been no studies at Sanglah General Hospital or in Indonesia regarding the relationship between total lymphocyte count and HAM in children. Based on the above background, this study aims to evaluate the prognostic value of the TLC at the time of admission to the occurrence of malnutrition in hospital in pediatric patients.

This study aims to evaluate the prognostic value of TLC at the time of admission to the occurrence of malnutrition in hospital in pediatric patients.

\section{Materials and methods}

A prospective cohort study was conducted from May to December 2019 in the Children's Ward at Sanglah General Hospital, Denpasar, Indonesia. An ethical approval was obtained by the Research Ethics Commission, Faculty of Medicine, Universitas Udayana/Sanglah General Hospital (No. 2360/UN14.2.2.VII.14/LP/2019).

\section{Subjects Recruitment}

Subjects in this study were all children aged 1 month to 18 years old who got treated in the Children's Ward at Sanglah General Hospital during the study periods. A follow-up was performed prospectively until patients were discharged from hospital.

Subjects were excluded from the study if they had been treated in the Pediatric Intensive Care Unit (PICU) during treatment, the subject died within the first 24 hours of treatment, had anasarca edema, aplastic anemia, malignant disease affecting the hematological system, had Acquired Immune Deficiency Syndrome (AIDS), dengue fever spectrum, systemic lupus erythematosus (SLE), patients with a history of chemotherapy therapy, long-term steroid use, and overweight or obesity. Subjects who moved to other hospital before their time to discharge from hospital, or subjects who returned from the hospital at their own request were stated as loss to follow-up.

\section{Data Collection}

The data obtained from the study included age, gender, nutritional status (on first day of admission), primary diagnosis, disease complexity, nutrition administration, and length of stay. HAM was defined as malnutrition that occurs during subjects' hospitalization, which was assessed by the criteria for weight loss (loss of body weight $>2 \%$ in weekly care, $>5 \%$ in monthly care, and $>10 \%$ in more-than-a -month care. TLC level was obtained from a complete blood count examination with flowcytometry method, and was subsequently expressed as dichotomous nominal categorical scale, which was classified as showed in Table $1 .^{8}$ Initial nutritional status was determined based on anthropometric data used the z-score value of weight/height based on the World Health Organization (WHO) Anthro Chart.

Table 1. Normal range of TLC level according to age. ${ }^{8}$

\begin{tabular}{lc}
\hline \multicolumn{1}{c}{ Age Groups } & Lymphocytes $(\mathbf{x 1 0} / \mathbf{L})$ \\
\hline 4 week & $2.8-9.1$ \\
2-6 month & $4.0-10.0$ \\
6 month-1 year & $4.0-12.0$ \\
1-6 year & $1.5-9.5$ \\
6-12 year & $1.5-7.0$ \\
12-18 year old female & $1.1-4.5$ \\
12-18 year old male & $1.1-4.5$ \\
\hline
\end{tabular}




\section{Statistical Analysis}

A consecutive sampling was done and the minimum sample size required was 120 samples. The analysis were to assess the relationship between total lymphocyte count and the incidence of HAM was carried out by making a 2x2 cross tabulation along with the calculation of relative risk (RR), the statistical test used was Chi-Square. Multivariate analysis was performed using logistic regression to control for confounding variables.

\section{Results}

From total population of 142 subjects, only 120 subjects were recruited consecutively and fulfilled the research criteria. Subjects that were excluded were 22 subjects, because 5 subjects we treated at PICU, 1 subject died within 1x24 hours, 7 subjects had malignant diseases, 2 subjects had AIDS, 3 subjects had SLE, 4 subjects had obesity. The research subjects consisted of 67 boys and 53 girls with a mean age of 88 months or 7 years and 4 months.

Out of 120 subjects, 55 subjects (45.8\%) were classified as having HAM. The characteristics of subjects who experience HAM were shown in Table 2. The characteristics of the two groups did not appear to be significantly different.

Table 3 showed the association between TLC and the incidence of HAM. Subjects who experienced HAM tended to have a low TLC and statistically significant differences were found. Table 4 provided the primary diagnosis of the subject based on the organ systems affected. Diagnosis in the respirology division was the most common (22\%) associated with HAM in this study. While, Table 5 described the multivariate analysis of the factors associated with HAM. There were no other significant risk factors associated with HAM.

\section{Discussion}

The incidence of malnutrition in the hospital in this study was $45.8 \%$, that is, 55 of the 120 subjects experienced a weight loss of more than $2 \%$ during a week's treatment or more than 5\% during a month's treatment or more than $10 \%$ during treatment more than a month.

Untreated hospital malnutrition will weaken the immune system, increase the risk of infection, slow wound healing, decrease gastrointestinal function, increase

Table 2. General characteristics of HAM subjects $(n=55)$.

\begin{tabular}{|c|c|c|c|}
\hline \multirow{2}{*}{ Variable } & \multicolumn{2}{|c|}{ Hospital Acquired Malnutrition } & \multirow{2}{*}{$p$-value } \\
\hline & Yes & No & \\
\hline Age (month), means \pm SD & $88.3 \pm 9.5$ & $74.9 \pm 7.5$ & $0.081^{\#}$ \\
\hline \multicolumn{4}{|l|}{ Sex, n (\%) } \\
\hline male & $30(25)$ & $37(31)$ & $0.360^{*}$ \\
\hline female & $25(20.8)$ & $28(23.2)$ & \\
\hline \multicolumn{4}{|l|}{ Complexities, n (\%) } \\
\hline single & $22(18.3)$ & $49(41)$ & $0.052^{*}$ \\
\hline multiple & $33(27.5)$ & $16(13.2)$ & \\
\hline \multicolumn{4}{|c|}{ Initial nutritional status, n (\%) } \\
\hline well nourished & $22(18.3)$ & $28(23.2)$ & $0.919 *$ \\
\hline under nourished & $33(27.5)$ & $37(31)$ & \\
\hline \multicolumn{4}{|l|}{ Nutritional route, $\mathrm{n}(\%)$} \\
\hline enteral & $52(43.3)$ & $58(48.2)$ & $0.369 * *$ \\
\hline parenteral & $3(2,5)$ & $7(6)$ & \\
\hline \multicolumn{4}{|l|}{ Length of stay, n (\%) } \\
\hline$\leq 7$ days & $16(13.2)$ & $20(16.5)$ & $0.665^{*}$ \\
\hline$>7$ to $\leq 30$ days & $31(25.8)$ & $39(32.5)$ & \\
\hline$>30$ days & $8(7)$ & $6(5)$ & \\
\hline \multicolumn{4}{|l|}{ Economic status, n (\%) } \\
\hline low & $37(30.8)$ & $50(41.7)$ & $0.238^{*}$ \\
\hline normal & $18(15)$ & $15(12.5)$ & \\
\hline
\end{tabular}

*Chi-square test; **Fisher test; "Independent-T test. 
Table 3. The association between TLC and the incidence of HAM.

\begin{tabular}{|c|c|c|c|c|}
\hline \multirow{2}{*}{$\begin{array}{c}\text { Total Lymphocyte } \\
\text { Count }\end{array}$} & \multicolumn{2}{|c|}{ HAM (n (\%)) } & \multirow{2}{*}{$\begin{array}{c}\text { RR } \\
(95 \% \mathrm{CI})\end{array}$} & \multirow{2}{*}{$p$-value* } \\
\hline & Yes & No & & \\
\hline Low & $34(61.8)$ & $21(38.2)$ & 1.913 & \multirow{2}{*}{0.002} \\
\hline Normal & $21(32.3)$ & $44(67.7)$ & $(1.272-2.879)$ & \\
\hline
\end{tabular}

*Chi-square test

dependence on ventilators, prolong hospital stay, and ultimately increase the cost of hospital care. ${ }^{8}$

For the approach to determining nutritional status in hospitalized children, the American Society for Parenteral and Enteral Nutrition (ASPEN) recommends a diagnostic approach that combines clinical manifestations, biochemical, and anthropometric parameters. ${ }^{9}$ ASPEN emphasizes that the overall patient diagnosis is important for detecting the risk of malnutrition, for prevent increased morbidity caused by malnutrition. ${ }^{9}$ One of the recommended laboratory parameters is lymphocyte examination, in addition to checking for albumin, prealbumin, and cholesterol. ${ }^{10,11}$

One of the efforts to identify the risk of HAM is to determine simple biomarkers that can be used as predictors of HAM. The biomarker studied in this study was the TLC. This study proved that the TLC had a significant relationship with the incidence of HAM ( $p=0.002)$. Subjects who had a low TLC (according to age) experienced HAM of $61.8 \%$, while subjects who had a normal TLC experienced HAM of $32.3 \%$. Subjects with a low TLC compared to a normal TLC had a 3.9-fold risk of developing HAM, with a 95\% confidence interval between 1.5 and 7.1. These results suggest that a low TLC can be used as a predictor of HAM. In the multivariate analysis, there were no variables other than lymphocyte levels which influenced the incidence of HAM.

Children are individuals who are very susceptible to malnutrition because of the high energy needed for growth and development, while energy reserves are limited. ${ }^{12}$ Malnutrition in children will trigger thymus atrophy which will reduce the number of thymus cells and if it continues will affect the development of peripheral lymphoid organs. The direct consequence of this condition is the occurrence of leukopenia, a decrease in the $\mathrm{CD} 4 / \mathrm{CD} 8$ ratio, and an increase in immature $\mathrm{T}$ cell levels in the periphery. ${ }^{12}$ Morphological changes in the epithelial cells of the thymus are associated with decreased production of thymus hormones during malnutrition. leptin and increased levels of glucocorticoid hormones in serum. ${ }^{13,14}$ The immune response from the epithelial surface is also influenced by malnutrition, namely in the form of intestinal mucosal changes such as microvillar hypotropia, decreased lymphocyte levels in Peyer patches and decreased secretion of immunoglobulins A. ${ }^{12,14}$

The changes in the body's immunity that have been described above make it easier for malnourished children to suffer from infections and if they are infected, the degree will tend to be severe. ${ }^{12}$ When an infection occurs, there is a change in metabolism in the infected individual,

Table 4. Primary diagnosis in patients with HAM $(n=55)$.

\begin{tabular}{lc}
\hline $\begin{array}{c}\text { Primary Diagnosis in Patients with HAM } \\
\text { According to Systems Organs Involved }\end{array}$ & n (\%) \\
\hline Nephrology & $5(8.5)$ \\
Gastro-hepatology & $11(20)$ \\
Neurology & $9(16)$ \\
Hemato-oncology & $10(18.5)$ \\
Respirology & $12(22)$ \\
Nutrition and metabolic disease & $3(5)$ \\
Infection and tropical disease & $5(10)$ \\
\hline
\end{tabular}


Table 5. Multivariate analysis of factors associated with HAM.

\begin{tabular}{lccc}
\hline \multicolumn{1}{c}{ Variable } & b & $\begin{array}{c}\text { RR } \\
(\mathbf{9 5 \%} \mathbf{C I})\end{array}$ & $\boldsymbol{p}$-value* \\
\hline Age & 0.216 & $1.244(0.695-2.227)$ & 0.462 \\
Sex & -0.395 & $1.023(0.277-1.635)$ & 0.383 \\
Complexities & -0.569 & $0.566(0.190-1.686)$ & 0.307 \\
Initial nutritional status & 0.76 & $1.689(1.031-2.644)$ & 0.337 \\
Nutritional route & -0.821 & $0.440(0.033-5.812)$ & 0.533 \\
Length of stay & -0.253 & $0.777(0.412-1.464)$ & 0.229 \\
Economic status & 0.529 & $1.698(0.717-4.021)$ & 0.689 \\
Total lymphocyte count & 1.776 & $3.907(1.599-7.199)$ & 0.001 \\
\hline
\end{tabular}

including energy metabolism, protein, and mineral. Infection conditions will increase energy requirements to fight the process of infection and depletion of glycogen and fat reserves. ${ }^{12}$ In individuals who experience infection, there will also be a decrease in appetite (anorexia) which makes the body more catabolic and worsens the condition of malnutrition. ${ }^{12}$ Long-term complications if this malnutrition is not treated are chronic malnutrition and morbidity and even mortality.

The condition of malnutrition will affect the body's immunity. Lymphocyte levels become low, the quality of lymphocytes is impaired so that children are prone to recurrent infections and inflammatory conditions tend to be severe because they are not handled optimally. ${ }^{13}$ In the future, there will be a tendency to experience recurrent malnutrition, especially when hospitalized.

Based on previous research, there is a strong association between low TLC $(<0.758)$ and malnutrition $(p<0.005) .{ }^{15}$ Individuals with a low TLC tend to experience recurrent infections which are prone to experiencing HAM. Other research found, there is a strong association between baseline low peripheral lymphocyte counts and malnutrition in hospitalized children $\left({ }^{\mathrm{P}}<0.003\right) .{ }^{16}$ Children with low lymphocyte levels have a higher risk of bacterial infection than normal lymphocyte levels and have a higher incidence of HAM. ${ }^{16}$

In this study, the primary diagnosis in patients with HAM was that of the respiratory organ system (22\%). Based on WHO data, respiratory disease, especially Acute Respiratory Infection (ARI), is the main cause of morbidity and mortality in the world. ARI is stated as one of the causes of consultation or hospitalization in health care facilities, especially in the childcare section. ${ }^{17,18}$ Based on a systematic review, in children with malnutrition there will be changes in both the natural and acquired immune systems. These changes can occur permanently, especially in the thymus organ. ${ }^{18}$ This condition makes children prone to recurrent infections. Infections that are closely related to malnutrition are in the gastrointestinal and respiratory systems. ${ }^{16}$

Further study needs to be examined to know when the lymphocyte levels will drop due to malnutrition. Another limitation of this study was unable to show the dynamics of lymphocyte changes during hospitalization due to the absence of repeated examinations.

\section{Conclusion}

This study proved that the low TLC as the risk of hospital malnutrition. TLC can be used as a predictor of the risk of hospital malnutrition in children hospitalized. Based on the results of this study, it can be suggested to check the TLC in each sick child who was admitted to the hospital on the first day of treatment. The results of these tests can be applied to early identification of the possibility of malnutrition in the hospital in treated patients.

\section{References}

1. Ghosh-Jerath S, Singh A, Jerath N, Gupta S, Racine EF. Undernutrition and severe acute malnutrition in children. BMJ. 2017; 359: j487788.

2. Sidiartha IGL. Insidens Malnutrisi Rawat Inap pada Anak Balita di Rumah Sakit Umum Pusat Sanglah Denpasar. Sari Pediatri. 2016; 9(6): 381. doi: 10.14238/sp9.6.2008.381-85.

3. Juliaty A. Malnutrisi rumah sakit pada bangsal anak Rumah Sakit Dr. Wahidin Sudirohusodo Makassar. Sari Pediatri. 2016; 15(2): 65-9.

4. Beser OF, Cokugras FC, Erkan T, Kutlu T, Yagci, RV. Evaluation 
of malnutrition development risk in hospitalized children. Nutr J. 2018; 48: 40-7.

5. McCarthy A, Delvin E, Marcil V, Belanger V, Marchand V, Boctor D, et al. Prevalence of malnutrition in pediatric hospitals in developed and in-transition countries: the impact of hospital practices. Nutrients. 2019; 11(2): 236. doi: 10.3390/nu11020236.

6. Walker WA, Watkins JB, Duggan C. Nutrition in pediatrics. Basic science and clinical applications. 4th ed. London: BC Decker; 2008.

7. Tyastarini AT, Saraswati MR. Hubungan jumlah limfosit total dengan status nutrisi pada pasien diabetes melitus tipe 2 rawat inap di Rumah Sakit Umum Pusat Sanglah Denpasar tahun 2014. E Jurn Med. 2017; 6(8): 1-8.

8. Nah EH, Kim S, Cho S, Cho HI. Complete blood count reference intervals and patterns of changes across pediatric, adult, and geriatric ages in korea. Ann Lab Med. 2018; 38(6): 503-11.

9. Gouveia MAC, Silva GAP. Hospital malnutrition in pediatric patients: a review. Ann Nutr Disord \& Ther. 2017; 4(2): 1042-8.

10. Tuokkola J, Hilpi J, Kolho KL, Orell H, Merras-Salmio L. Nutritional risk screening-a cross-sectional study in a tertiary pediatric hospital. J Health Popul Nutr. 2019; 38(1): 8. doi: 10.1186/s41043019-0166-4.

11. Ong SH, Chee WSS, Lapchmanan LM, Ong SN, Lua ZC, Yeo JX. Validation of the subjective global nutrition assessment (SGNA) and screening tool for the assessment of malnutrition in paediatrics (STAMP) to identify malnutrition in hospitalized Malaysian children. J Trop Pediatr. 2019; 65(1): 39-45.

12. Ibrahim MK, Zambruni M, Melby CL, Melby PC. Impact of childhood malnutrition on host defense and infection. Clin Microbiol Rev. 2017; 30(4): 919-71.

13. Keller U. Nutritional laboratory markers in malnutrition. J Clin Med 2019; 8(6): 775. doi: 10.3390/jcm8060775.

14. Rocha NP, Fortes RC. Total lymphocyte count and serum albumin as predictors of nutritional risk in surgical patients. Arq Bras Cir Dig. 2015; 28(3): 193-6.

15. González Madroño A, Mancha A, Rodríguez FJ, de Ulibarri JI, Culebras J. The use of biochemical and immunological parameters in nutritional screening and assessment. Nutr Hosp. 2011; 26(3): 594-601.

16. Naess A, Nilssen SS, Mo R, Eide GE, Sjursen H. Role of neutrophil to lymphocyte and monocyte to lymphocyte ratios in the diagnosis of bacterial infection in patients with fever. Infection. 2017; 45(3): 299-307.

17. Hecht C, Weber M, Grote V, Daskalou E, Dell'Era L, Flynn D, et al Disease associated malnutrition correlates with length of hospital stay in children. Clin Nutr. 2015; 34(1): 53-9.

18. Cohen S, Danzaki K, Maciver NJ. Nutritional effects on T-cell immunometabolism. Eur J of Immunol. 2017; 47(2): 225-35. 